\title{
Status Mikrobiologi Tepung Ikan Rucah yang Diberi Ekstrak Daun Kersen sebagai Antibakteri pada Berbagai Lama Penyimpanan
}

\author{
Status of Microbiology Fish Meal Given Cherry Leaf Extract as Antibacterial in Various \\ Storage Periods
}

Tito Maulana Akbar, Baginda Iskandar Moeda T., dan Retno Iswarin Pujaningsih

Fakultas Peternakan dan Pertanian, Universitas Diponegoro

Corresponding e-mail : tito.maulanaakbar@gmail.com

\begin{abstract}
This study aimed to determine and evaluate the quality of microbiological of fishmeal given cherry leaf extract on various storage periods. Cherry leaf extract was extracted by using soxhletation method. The concentration of cherry leaf extract used was $50 \%$. Fish meal was added with cherry leaf extract in a ratio of 10: $1(\mathrm{w} / \mathrm{v})$, given treatment storage duration of each $\mathrm{T}_{0}(0$ storage time $), \mathrm{T}_{1}\left(2^{\text {nd }}\right.$ storage time $)$ and $\mathrm{T}_{2}\left(4^{\text {th }}\right.$ storage time $)$. Design used was Completely Randomized Design (CRD) with 3 treatments and 5 replications. Parameters observed were total bacteria, Gram +/- bacteria and identification of Escherichia coli and Salmonella sp. qualitatively. Storage time treatment $\left(\mathrm{T}_{1}\right)$ was significantly different $(\mathrm{P}<0.05)$ on total bacteria, but not significantly different against Gram $+/$ - bacteria. Qualitatively, Escherichia coli and Salmonella sp bacteria were not found in the sample used. Cherry leaf extract added to fish meal can reduce the total number of bacteria, the growth of Gram-bacteria, Escherichia coli and Salmonella sp. during storage.
\end{abstract}

Key words: fishmeal, cherry leaf extract, quality of microbiological, soxheltation.

\begin{abstract}
ABSTRAK
Penelitian ini bertujuan untuk mengetahui dan mengkaji kualitas tepung ikan rucah yang diberi ekstrak daun kersen secara mikrobiologi pada berbagai lama penyimpanan. Ekstrak daun kersen diekstraksi menggunakan metode sokletasi. Konsentrasi ekstrak daun kersen yang digunakan adalah 50\%. Tepung ikan rucah ditambahkan ekstrak daun kersen dengan perbandingan $1: 10(\mathrm{v} / \mathrm{w})$, diberi perlakuan lama penyimpanan masing-masing $\mathrm{T}_{0}$ (lama penyimpanan minggu ke -0), $\mathrm{T}_{1}$ (lama penyimpanan minggu ke-2) dan $\mathrm{T}_{2}$ (lama penyimpanan minggu ke - 4). Rancangan yang digunakan adalah Rancangan Acak Lengkap (RAL) dengan 3 perlakuan dan 5 ulangan. Parameter yang diamati adalah total bakteri, bakteri Gram +/- dan identifikasi Escherichia coli dan Salmonella $s p$. secara kualitatif. Perlakuan lama penyimpanan berbeda nyata $(\mathrm{P}<0,05)$ terhadap total bakteri, namun tidak berbeda nyata $(\mathrm{P}>0,05)$ terhadap bakteri Gram +/-. Secara kualitatif, tidak ditemukan bakteri Escherichia coli dan Salmonella sp. pada sampel yang digunakan. Ekstrak daun kersen yang ditambahkan pada tepung ikan rucah mampu mengurangi jumlah total bakteri, menekan bakteri Gram negatif, Escherichia coli dan Salmonella sp. selama penyimpanan.
\end{abstract}

Kata Kunci: Tepung ikan rucah, ekstrak daun kersen, kualitas mikrobiologi, sokletasi.

\section{PENDAHULUAN}

Ikan rucah merupakan hasil perikanan tangkap yang berukuran kecil atau limbah perikanan dari industri yang kurang memiliki nilai ekonomis. Ketersedian dan kuantitas ikan rucah melimpah pada musim tangkap nelayan. Ikan rucah digunakan sebagai bahan pakan alternatif karena memiliki harga yang relatif murah dengan kandungan protein tinggi yaitu berkisar antara $40-65 \%$. Harga ikan rucah berkisar antara Rp. 2.500 -
$4.000 / \mathrm{kg}$ (Hidayatullah et al., 2014). Kandungan nutrien yang terdapat dalam ikan rucah meliputi protein kasar 58,97\%, abu $27,89 \%$, lemak $6,54 \%$, serat kasar $1,64 \%$ (Utomo et al., 2013). Kualitas pada tepung ikan sangat dipengaruhi oleh jenis ikan yang digunakan proses pengolahan serta metode pengawetan yang dilakukan. Permasalahan dari tepung ikan rucah yaitu memiliki kadar protein tinggi menjadi media yang baik untuk pertumbuhan mikroba, sehingga kualitas 
tepung ikan dapat menurun selama proses penyimpanan.

Penurunan kualitas selama proses penyimpanan terjadi karena interaksi bahan pakan dengan kondisi organisme dan lingkungan (Suparjo, 2010). Batasan maksimum cemaran bakteri Escherichia coli dan Salmonella sp. adalah $<3$ per g dan negatif per $\mathrm{g}$ dari $25 \mathrm{~g}$ sampel (Standar Nasional Indonesia, 1996). Penurunan kualitas pakan selama penyimpanan dapat dihindari dengan penambahan bahan yaitu antijamur dan antibakteri.

Pengawetan merupakan suatu cara agar bahan dapat disimpan lebih lama dan dapat dipertahankan sifat fisik, kimia maupun mikrobiologinya. Pengawetan dapat dilakukan dengan penjemuran menggunakan sinar matahari ataupun oven. Penjemuran bertujuan untuk mengurangi kadar air bahan, sehingga menghambat bakteri untuk tumbuh. Penggunaan bahan pengawet kimia dapat dilakukan seperti antijamur, antikutu bahan pakan yang akan disimpan, namun akan menghasilkan residu yang berbahaya bagi manusia. Penggunaan bahan pengawet alami digunakan untuk menggantikan bahan pengawet buatan yaitu dengan menggunakan daun kersen yang mempunyai senyawa antibakteri.

Kersen (Muntingia calabura L.) adalah sejenis pohon yang memiliki buah yang kecil dan manis. Tanaman kersen merupakan tanaman asli dari benua Amerika, namun telah tersebar di wilayah Asia. Tanaman kersen banyak ditemukan disetiap lahan kosong atau di tepi jalan (Ami, 2016). Bagian- bagian tanaman kersen yaitu batang, buah dan daunnya digunakan sebagai obat tradisional. Daun kersen memiliki potensi sebagai antibakteri karena mengandung flavonoid, saponin dan tanin (Zakaria et al., 2006). Penelitian ini bertujuan untuk mengetahui dan mengkaji pengaruh perbedaan lama penyimpanan $(0,2,4$ minggu) terhadap tepung ikan rucah yang ditambahkan ekstrak daun kersen $1 \%$ (1/10 v/w) terhadap status mikrobilogi. Penelitian ini bermanfaat untuk memperoleh informasi mengenai lama penyimpanan terbaik pada penyimpanan $(0,2,4$ minggu).

\section{MATERI DAN METODE}

Penelitian ini dilaksanakan pada bulan bulan Agustus 2017 sampai dengan Mei 2018 di Laboratorium Teknologi Pakan, Fakultas Peternakan dan Pertanian Universitas Diponegoro, Semarang. Analisis Mikrobiologi di Laboratorium Analisis Kesehatan SMK Theresiana, Semarang.

Materi yang digunakan dalam penelitian ini yaitu alat yang terdiri dari timbangan digital, plastik cor, dandang, blender, saringan, seperangkat alat sokletasi, tabung reaksi, cawan petri, mikroskop, pipet, jarum ose, bunsen dan inkubator.

Bahan terdiri tepung ikan rucah, ekstrak daun kersen, etanol 97\%, $\mathrm{NaCl}$ 0,85\%, Medium NA (Nutrient Agar), Media MacConkey, larutan kristal violet, iodin, alkohol, media biokimia, reagen kovac, reagen napthol reagen, methyl red dan $\mathrm{KOH}$ creatin.

Metode yang digunakan dalam penelitian ini meliputi rancangan penelitian, prosedur penelitian dan analisis data.

Penelitian ini menggunakan Rancangan Acak Lengkap (RAL) dengan 3 perlakuan 5 ulangan, perlakuan yang dilakukan sebagai berikut :

$\mathrm{T} 1$ : Tepung ikan $+1 \%(\mathrm{v} / \mathrm{w})$ ekstrak daun kersen lama penyimpanan 0 minggu.

$\mathrm{T} 2$ : Tepung ikan $+1 \%$ (v/w) ekstrak daun kersen lama penyimpanan 2 minggu.

T3 : Tepung ikan $+1 \%(\mathrm{v} / \mathrm{w})$ ekstrak daun kersen lama penyimpanan 4 minggu.

Prosedur penelitian ini meliputi tahap persiapan, tahap perlakuan dan tahap analisis.

\section{Tahap Persiapan}

Pembuatan tepung ikan rucah dan ekstrak daun kersen. Tahapan pembuatan tepung ikan rucah yaitu pengadaan ikan rucah, pengukusan selama 1 jam, penjemuran selama 3-4 hari, penggilingan dan penyaringan. Tahapan pembuatan serbuk 
daun kersen yaitu pemetikan, pencucian dengan air mengalir, pengeringan udara, pengeringan menggunakan oven dengan suhu $60{ }^{\circ} \mathrm{C}$ selama 24 jam, penggilingan dan penyaringan. Pembuatan ekstrak daun kersen menggunakan metode ekstraksi sokletasi.

\section{Tahap Perlakuan}

Tepung ikan rucah dicampur dengan hasil ekstraksi (sokletasi) daun kersen konsentrasi 50\% (1: 1, ekstrak daun kersen : etanol 97\%) dengan pencampuran ekstrak $100 \mathrm{ml}$ per $1000 \mathrm{~g}$ berat tepung ikan rucah dengan perbandingan 1:10. Pengamatan dilakukan pada minggu ke- 0 , ke- 2 dan ke-4 pada penyimpanan suhu ruang dan tidak dikemas.

\section{Total Bakteri}

Analisis jumlah bakteri dilakukan berdasarkan (Fardiaz, 1992) menggunakan metode tuang/pour plate. Pengujian jumlah bakteri dilakukan dengan menyiapkan 4 buah tabung reaksi steril dan memberi tanda $10^{-1}$, $10^{-2}, 10^{-3}$ dan $10^{-4}$, kemudian menambahkan $\mathrm{NaCl} \quad 0,85 \%$ steril sebanyak $9 \mathrm{ml}$. Menimbang tepung ikan sebanyak $1 \mathrm{~g}$, kemudian dimasukkan dalam tabung $10^{-1}$ dan dihomogenkan.

Melakukan pengenceran sampai dengan tabung $10^{-4}$ dengan mengambil $1 \mathrm{ml}$ dari tabung sebelumnya dan menambahkan pada tabung selanjutnya kemudian dihomogenkan. Menyiapkan 5 buah cawan petri dan memberi tanda label blanko dan pengenceran $10^{-1}, 10^{-2}, 10^{-3}, 10^{-4}$, kemudian memasukkan $1 \mathrm{ml} \mathrm{NaCl} 0,85 \%$ pada blanko dan $1 \mathrm{ml}$ dari pengenceran bahan pada cawan petri sesuai dengan tanda masing-masing. Menambahkan media NA (Nutrient Agar) sebanyak $20 \mathrm{ml}$, kemudian homogenisasi dan menunggu sampai agar memadat.

Menginkubasi pada inkubator pada suhu $37^{\circ} \mathrm{C}$ selama $18-24$ jam. Menghitung jumlah koloni yang tumbuh. Data yang dilaporkan berdasarkan perhitungan Standar Plate Count (SPC). Perhitungan jumlah koloni adalah sebagai berikut:
Jumlah Bakteri $=$ Jumlah Koloni $\mathrm{x}$ Volume yang ditanam $x$ Pengenceran

\section{Bakteri Gram}

Pengujian pewarnaan Gram +/dilakukan dengan memanaskan ose untuk pengambilan sampel, kemudian meletakkan sampel pada kaca objektif. Meneteskan larutan kristal violet dan menunggu selama 1 menit, kemudian bilas dengan air mengalir posisi kaca objek miring $45^{\circ}$. Menuangkan larutan iodin dan menunggu selama 1 menit. Bilas dengan air kembali, kemudian meneteskan larutan alkohol selama 10-30 detik. Membilas dengan air, kemudian direndam dengan larutan safranin selama 10 - 30 detik. Mencuci dengan air dan keringkan, kemudian mengamati menggunakan mikroskop.

\section{Escherichia coli dan Salmonella sp.}

Pengujian identifikasi Escherichia Coli dan Salmonella sp. dilakukan dengan mengambil suspensi pengenceran $10^{-1}$ menggunakan ose secara aseptis, kemudian diinokulasikan pada media MacConkey dan diinkubasikan pada suhu $37^{\circ} \mathrm{C}$ selama 18 24 jam. Mengamati koloni yang terbentuk berwarna merah yang menunjukkan memfermentasikan laktosa, kemudian ditanam pada media biokimia yang memiliki karakteristik yang berbeda. Media uji biokimia meliputi: Indol, Motil, Glukosa, Laktosa, Maltosa, Manitol, Sakarosa, Triple Sugar Iron Agar (TSIA), Urea, Voges Proskauer (VP), Methyl Red (MR), Simon Citrate secara aseptis, kemudian diinkubasikan pada suhu $37^{\circ} \mathrm{C}$ selama 18 24 jam. Penambahan masing-masing 5 tetes reagen kovac untuk media Indol, apabila positif akan terbentuk cincin merah, reagen napthol dan $\mathrm{KOH}$ creatin untuk media Voges Proskauer (VP) reagen methyl red untuk media methyl red. 


\section{HASIL DAN PEMBAHASAN}

\section{Total Bakteri}

Berdasarkan hasil penelitian pada (Tabel 1.) yang menunjukkan bahwa tepung ikan yang diberi ekstrak daun kersen pada berbagai lama penyimpanan berbeda terhadap total bakteri. Hasil rataan total bakteri $\mathrm{T}_{1}\left(3,08 \times 10^{5} \mathrm{cfu} / \mathrm{g}\right)$ berbeda $(\mathrm{P}<0,05)$ lebih tinggi dari $\mathrm{T}_{0}\left(1,16 \times 10^{4}\right.$ $\mathrm{cfu} / \mathrm{g})$ dan $\mathrm{T}_{2}\left(1,44 \times 10^{4} \mathrm{cfu} / \mathrm{g}\right)$, sedangkan untuk $\mathrm{T}_{0}$ dan $\mathrm{T}_{2}$ tidak berbeda.

Tabel 1.Hasil Total Bakteri, Bakteri Gram, Identifikasi Escherichia coli dan Salmonella sp.

\begin{tabular}{|c|c|c|c|}
\hline Parameter & $\mathrm{T} 1$ & $\mathrm{~T} 2$ & T3 \\
\hline Total & & & \\
\hline $\begin{array}{l}\text { Bakteri } \\
\text { (cfu/g) }\end{array}$ & $\begin{array}{c}1,16 \times \\
10^{4}\end{array}$ & $\begin{array}{c}3,08 \times \\
10^{5}\end{array}$ & $\begin{array}{c}1,44 \times \\
10^{4}\end{array}$ \\
\hline $\begin{array}{l}\text { Bakteri } \\
\text { Gram * }\end{array}$ & 3,6 & 4 & 4 \\
\hline $\begin{array}{l}\text { Escherichia } \\
\text { coli } * *\end{array}$ & Negatif & Negatif & Negatif \\
\hline $\begin{array}{l}\text { Salmonella } \\
\text { sp. ** }\end{array}$ & Negatif & Negatif & Negatif \\
\hline
\end{tabular}

Pertumbuhan bakteri tertinggi pada $\mathrm{T}_{2}$ dan mengalami penurunan di minggu ke4, diduga bakteri mengalami pertumbuhan fase $\log$ dan fase kematian. Fase log ditandai dengan jumlah bakteri yang meningkat dari $\mathrm{T}_{0}\left(1,16 \times 10^{4} \mathrm{cfu} / \mathrm{g}\right)$ ke $\mathrm{T}_{1}\left(3,08 \times 10^{5}\right.$ $\mathrm{cfu} / \mathrm{g}$ ), sedangkan fase kematian ditandai dengan jumlah bakteri yang berkurang $T_{1}$ $\left(3,08 \times 10^{5} \mathrm{cfu} / \mathrm{g}\right)$ ke $\mathrm{T}_{2}\left(1,44 \times 10^{4} \mathrm{cfu} / \mathrm{g}\right)$. Menurut Buckle et al. (1985), bakteri mengalami pertumbuhan yang terbagi menjadi 4 fase yaitu fase lag, fase log, fase tetap dan fase kematian. Fase lag atau fase lambat merupakan fase bakteri menyesuaikan diri dengan lingkungan yang baru. Fase log merupakan fase pertumbuhan bakteri meningkat secara eksponsial. Fase tetap merupakan fase bakteri berhenti tumbuh dipengaruhi oleh nutrisi yang tersedia. Fase kematian merupakan bakteri mulai menurun jumlahnya dan tidak dapat tumbuh kembali, kecuali pada media baru.

Kematian mikroba dapat disebabkan oleh beberapa hal diantaranya yaitu faktor nutrisi atau zat antibakteri. Ekstrak daun kersen mengandung senyawa bioaktif yaitu tannin, saponin dan flavonoid yang dapat digunakan sebagai antibakteri. Zakaria et al. (2006) melaporkan bahwa terdapat aktivitas antimikroba pada ekstrak daun kersen yaitu senyawa tanin, saponin dan flavonoid. Surjowardojo et al. (2014) menyatakan bahwa ekstrak daun kersen memiliki kadar flavonoid yang lebih banyak dibandingkan dengan tanin dan saponin, flavonoid, digunakan sebagai antimikroba dan antikanker. Konsentrasi antibakteri berpengaruh terhadap daya hambat bakteri. Konsentrasi ekstrak daun kersen yang digunakan yaitu 50\% tergolong ke dalam konsentrasi kuat. Menurut Arum et al. (2012), semakin tinggi konsentrasi ekstrak memiliki daya hambat yang tinggi terhadap pertumbuhan mikroba. Prasetyanti et al. (2016) melaporkan bahwa konsentrasi 20\% ekstrak daun kersen dapat digunakan sebagai teat dipping pada sapi perah karena menurunkan jumlah bakteri dan nilai CMT.

Flavonoid yang terkandung dalam ekstrak daun kersen akan menghambat atau merusak pertumbuhan bakteri. Cushnie dan Lamb (2005) melaporkan bahwa flavonoid memiliki beberapa mekanisme untuk menghambat pertumbuhan bakteri atau merusak diantaranya yaitu dengan menghambat sintesis asam nukleat, fungsi membran dan metabolisme energi. Hal ini diperkuat oleh pendapat Mahardika et al. (2014) flavonoid akan bekerja menghambat metabolisme energi, yang menyebabkan sel berhenti beraktivitas atau mati.

\section{Bakteri Gram}

Berdasarkan hasil penelitian pada (Tabel 1.) yang menunjukkan bahwa tepung ikan yang diberi ekstrak daun kersen pada berbagai lama penyimpanan tidak berbeda terhadap bakteri Gram +/-. Hasil rataan skor bakteri Gram +/- $\mathrm{T}_{0}(3,6) \mathrm{T}_{1}$ (4) dan $\mathrm{T}_{2}(4)$ tidak berbeda $(\mathrm{P}<0,05)$. Perlakuan $\mathrm{T}_{1}$ 
ditemukan bakteri Gram -, namun pada $\mathrm{T}_{2}$ dan $\mathrm{T}_{3}$ bakteri Gram negatif tidak ditemukan,hal ini diduga bakteri Gram negatif mati oleh flavonoid dari ekstrak daun kersen. Menurut Poeloengan dan Praptiwi (2010), flavonoid akan menghentikan kerja sel bakteri dengan mendenaturasi protein. Dinding sel yang terkena flavonoid kehilangan permeabilitas sel.

Bakteri Gram negatif memiliki ketebalan dinding yang tipis sehingga cairan mudah masuk. Pelczar dan Chan (1986) menyatakan bahwa bakteri Gram negatif memiliki dinding yang tipis dibandingkan dengan bakteri Gram positif. Lingga dan Rustama (2005) menyatakan bakteri Gram negatif memiliki dinding sel yang kurang rentan terhadap antimikroba, namun bakteri Gram negatif dapat mati dengan antimikroba yang memiliki konsentrasi yang pekat. bahan pakan yang digunakan juga berbeda.

\section{Escherichia coli}

Berdasarkan hasil peneltian pada (Tabel 1.) Identifikasi Escherichia coli menunjukkan bahwa tepung ikan yang diberi ekstrak daun kersen pada berbagai lama penyimpanan tidak mengandung bakteri Escherichia coli secara keseluruhan, namun ditemukan 1 sampel positif bakteri Escherichia coli. Menurut Standar Nasional Indonesia (2009), bahan pangan dari ikan memiliki batas cemaran maksimum untuk bakteri Escherichia coliadalah $<3$ g. Bahan pangan atau pakan tidak layak konsumsi apabila melebihi standar yang ditetapkan. Bakteri Escherichia coli merupakan bakteri patogen yang menyebabkan penyakit pada saluran pencernaan. Suwito (2010) melaporkan bakteri Escherichia coli dapat menyebabkan infeksi pada saluran pencernaan yang biasa disebut dengan kolobasillosis pada unggas, sedangakan pada anak sapi dapat menyebabkan diare. Rahmawati et al. (2014) menyatakan penyebaran bakteri Escherichia coli dari pakan dan lingkungan yang kurang higenis.

Proses pembuatan tepung ikan mengalami penjemuran dan penggilingan. Penjemuran bertujuan untuk menurunkan kadar air dari bahan. Kadar air yang rendah menghambat pertumbuhan bakteri. Menurut Buckle et al. (1985), bakteri tumbuh pada aktivitas air 0,91, sedangkan jamur dan khamir lebih rendah.

\section{Salmonella sp.}

Berdasarkan hasil peneltian pada (Tabel 1.) identifikasi Salmonella $s p$. menunjukkan bahwa tepung ikan yang diberi ekstrak daun kersen pada berbagai lama penyimpanan $(0,2,4$ minggu $)$ tidak mengandung bakteri Salmonella $s p$. Menurut Standar Nasional Indonesia (2009), batas cemaran maksimum bakteri Salmonella sp. pada bahan pangan atau pakan dari ikan yaitu negatif per $25 \mathrm{~g}$. Bahan pangan atau pakan tidak layak konsumsi apabila melebihi standar yang ditetapkan.

Menurut Afriyani et al. (2016), bakteri Salmonella sp. menyebabkan penyakit pullorum atau berak kapur pada unggas. Bakteri Salmonella sp. dapat menyebar melalui udara dan dapat menular dengan cepat. Ikawikanti et al. (2012) melaporkan penularan bakteri Salmonella sp. berasal dari kontak induk ke anak ayam dan kontak ayam sakit dengan ayam sehat, pakan dan air yang tercemar serta kotoran..

\section{KESIMPULAN}

Ekstrak daun kersen yang ditambahkan pada tepung ikan rucah mampu mengurangi jumlah total bakteri, menekan bakteri Gram negatif, Escherichia coli dan Salmonella sp. selama penyimpanan.

\section{DAFTAR PUSTAKA}

Afriyani, Darmawi, Fakhrurrazi, Z.H. Manaf, M. Abrar dan Winaruddin. 2016. Isolasi bakteri Salmonella sp. pada feses anak ayam broiler di Pasar UleeKareng, Banda Aceh. J. Medika Veterinaria $1(10): 74-76$.

Ami, M. S. 2016. Kajian daya antibakteri etanol kulit batang dan buah kersen (Muntingia calabura) terhadap 
bakteri Escherichia coli dan Staphylococcus aureus secara in vitro. Prosiding Seminar Biologi. Surabaya, 20 Februari. 2016. Universitas Negeri Surabaya. $162-166$.

Arum, Y.P., Supartono dan Sudarmin. 2012. Isolasi dan uji daya antimikroba ekstrak daun kersen (Muntigia calabura). J.MIPA 35 (2) : 165 - 174.

Buckle, K.A., R.A. Edward, G.H. Fleet dan M. Wotton. 1985. Ilmu Pangan. Universitas Indonesia Press, Jakarta.

Cushnie, T.P.T. dan A. J. Lamb. 2005. Antimicrobial activity of flavonoid. International Journal of Antimicrobial Agents $26: 343356$.

Fardiaz, S. 1993. Analisis Mikrobiologi Pangan. Raja Grafindo Persada, Jakarta.

Hidayatulllah, F.N., I.F. Djunaidi dan M.H. Natsir. 2014. Pengaruh tingkat penggunaan tepung ikan rucah nila (Oreochromis niloticus) dalam pakan terhadap penampilan produksi ayam buras. Fakultas Peternakan, Universitas Brawijaya, Malang.

Ikawikanti, A., M.C. Padaga dan D.A. Oktabiane. 2012. Isolasi dan karakterisasi Salmonella spp. pada lingkungan peternakan ayam broiler di Kota Malang. Fakultas Peternakan. Universitas Brawijaya, Malang.

Lingga, M.E., dan M.M. Rustama. 2005. Uji aktivitas antibakteri dari ekstrak air dan etanol bawang putih (Allium sativum L.) terhadap bakteri Gram negatif dan Gram positif yang diisolasi dari udang dogol (Metapenaeus monoceros), udang lobster (Panulirus sp.) da udang rebon (Mysis dan Acetes). Universitas Padjajaran, Sumedang.

Mahardika, H. A., Sarwiyono dan P. Surjowardjojo. 2014. Ekstrak metanol daun kersen (Muntingia calabura L.) sebagai antimikroba alami terhadap bakteri Staphylococcus aureus penyebab mastitis subklinis pada sapi perah. J. Ternak Tropika 2 (4) : $15-$ 22.

Pelczar, M.J. dan E.C.S. Chan. 1986. Dasar dasar Mikrobiologi. Universitas Indonesia Press, Jakarta.

Poeloengan, M. dan Praptiwi. 2010. Uji aktivitas antibakteri ekstrak kulit buah manggis (Garcinia mangostana L.) Media Litbang Kesehatan 20 (2) : 65 -69 .

Prasetyanti, D. R., C. Budiarti dan D.W. Harjanti. 2016. Efektifitas daun kersen (Muntingia calabura L.) dalam menurunkan jumlah bakteri dalam susu dan peradangan pada ambing sapi perah. J. Ilmu-ilmu Peternakan 1 (19) : $10-16$.

Rahmawati, N. E. Sudjarwo dan E. Widodo. 2014. Uji aktivitas ekstrak herbal terhadap bakteri Eschrichia coli. J. Ilmu-ilmu Peternakan.8978 24 (3) : $24-31$.

Standarisasi Nasional Indonesia. 1996. Tentang Tepung Ikan/Bahan Baku Pakan No. 01-2715-1996. Dewan Standarisasi Nasional, Jakarta.

Standarisasi Nasional Indonesia. 2009. Batas Maksimum Cemaran Mikroba dalam Pangan. No. 7388-1996. Badan Standarisasi Nasional, Jakarta.

Suparjo. 2010. Teknik Penyimpanan Pakan : Kerusakan Bahan Pakan Selama Penyimpanan. Fakultas Peternakan. Universitas Jambi, Jambi.

Surjowardojo, P., Sarwiyono, I. Thohari dan A. Ridhowi. 2014. Quantitative and qualitative phyotochemicals analysis of Muntingia calabura. J of Bioloogy, Agriculture and Healthcare. 16 (4) : $84-88$. 
Suwito, W. 2010. Monitoring Salmonella sp. dan Escherichia Coli dalam bahan pakan ternak. Buletin Peternakan 34 (3) : $165-168$.

Utomo, N. B. P., Susan dan M. Setiawati. 2013. Peran tepung ikan dari berbagai bahan baku terhadap pertumbuhan lele sangkuriang Clarias sp. J. Akuakultur Indonesia. 12 (2): 158 168.
Zakaria, Z. A., C. A. Fatimah, A. M. Mat Jais, H. Zaiton, E.F.P Hernie, M.R. Sulaimam, M. N. Somchit, M. Thenamutha dan D. Kasthuri. 2006. The in vitro antibacterial activity of Muntingia calabura extract. International Journal of Pharmacology. 2 (4) : 439 - 442. 